Z. Klin. Chem. Klin. Biochem.

13. Jg. 1975, S. 291-297

\title{
A Combined Adsorption-Gel Filtration Technique for the Determination of the Cortisol-Binding Capacity of Transcortin
}

\author{
By U. Schwartz ${ }^{1}$ ) and J. Hammerstein \\ Abteilung für Gynäkologische Endokrinologie, Klinikum Steglitz der Freien Universität Berlin, Germany
}

(Eingegangen am 15. März/18. Oktober 1974)

Summary: A combined adsorption-gel filtration technique has been developed for the quantitation of the cortisol-binding capacity of transcortin: Endogenous steroids are removed from plasma by adsorption on uncoated charcoal. Saturation of the "stripped" binding sites of transcortin is accomplished by equilibrating the sample with a definite amount of labeled cortisol of low specific activity $(0.1 \mu \mathrm{Ci} / \mu \mathrm{g})$. Transcortin-bound $\left[4 \cdot{ }^{14} \mathrm{C}\right]$ cortisol is isolated by gel filtration over Sephadex G-50 at $4{ }^{\circ} \mathrm{C}$ and measured by liquid scintillation counting. The cortisol-binding capacity of transcortin is calculated directly on the basis of the known specific activity of cortisol. The modification described eliminates methodological disadvantages associated with the original gel filtration procedures, i. e. the possible interference of various endogenous steroids with cortisol binding to transcortin, and the necessity of fluorometric or colorimetric determination of protein-bound cortisol. The values of the cortisol-binding capacity of transcortin in plasma obteined by this simplified assay are in close agreement with results reported in the literature (mean $\pm \mathrm{S}$. D.): healthy males $261 \pm 23 \mu \mathrm{g} / \mathrm{l}$ of transcortin-bound cortisol $(\mathrm{n}=13)$, healthy nonpregnant females $255 \pm 31 \mu \mathrm{g} / \mathrm{l}(\mathrm{n}=15)$, and pregnant females prior to delivery $560 \pm 82 \mu \mathrm{g} / \mathrm{l}(\mathrm{n}=12)$.

\section{Kombinierte Adsorptions-Gelfiltrationstechnik zur Bestimmung der Cortisol-Bindungskapazität von Transcortin}

Zusammenfassung: Eine kombinierte Adsorptions-Gelfiltrationstechnik zur Bestimmung der Transcortin-Bindungskapazität für Cortisol (TC-BC) wird beschrieben. Das Verfahren besteht aus folgenden Schritten: Entfernung der endogenen Steroide aus dem Plasma durch Adsorption an Aktivkohle; Sättigung der Transcortin-Bindungsstellen mit einer definierten Menge an $\left[4-{ }^{14} \mathrm{C}\right]$ Cortisol niedriger spezifischer Aktivität $(0,1 \mu \mathrm{Ci} / \mu \mathrm{g})$; Isolierung der Transcortin-gebundenen Cortisolfraktion durch Sephadex-G-50-Gelfiltration bei $4{ }^{\circ} \mathrm{C}$; Bestimmung der Transcortin-gebundenen Radioaktivität mittels Flüssigkeitsszintillationsmessung; direkte.TC-BC-Berechnung mit Hilfe der vorgegebenen spezifischen Aktivität der Cortisolsättigungslösung. Das dargelegte Verfahren erfüllt die methodischen Zuverlässigkeitskriterien. Die Einführung des Adsorptionsschrittes bringt gegenüber den Originalgelfiltrationstechniken wesentliche Verbesserungen hinsichtlich Spezifität, Richtigkeit und Praktikabilität mit sich: Ausschluß einer potentiellen unspezifischen Cortisolverdrängung von den Transcortin-Bindungsstellen in vitro durch konkurrierende endogene Steroide; Ermöglichung einer Isotopenmeßtechnik zur quantitativen Endbestimmung anstelle der unzuverlässigen und aufwendigen kolorimetrischen bzw. fluorometrischen Analyse des körpereigenen Cortisolspiegels. Die vereinfachte Methode entspricht in ihren Resultaten den aus der Literatur bekannten Werten. Die damit ermittelte Transcortin-Bindungskapazität betrug bei gesunden Männern $261 \pm 23 \mu$ g Transcortin-gebundenes Cortisol pro 1 Plasma (Mittelwert \pm Standardabweichung; $\mathrm{n}=13$ ), bei gesunden nichtgraviden Frauen $255 \pm 31 \mu \mathrm{g} / \mathrm{l}(\mathrm{n}=15)$ und bei Frauen im 10. Schwangerschaftsmonat $560 \pm 82 \mu \mathrm{g} / 1$ $(n=12)$.

\section{Introduction}

The development of pharmacological models to assess the estrogenicity of contraceptive steroids in man still represents an important objective of research in reproductive biology. Transcortin (synonym: corticosteroid-binding globulin $=\mathrm{CBG}$ ) has been shown to be a most specific indicator of estrogenic activity responding with a dose-correlated elevation of its cortisol-binding capacity to estrogen administration
(1). This parameter therefore seems to be particularly suited to serve as a bioassay facilitating quantitative comparisons of the estrogenic potency of hormonal substances in the human.

1) This work is taken from a dissertation submitted by U. Schwartz to the Freie Universität Berlin (1973) in fulfillment of the requircments for the degree of Doctor of Medicine. Parts of this paper have been presented at the Eighth Acta cndocrinologica Congress in Copenhagen, July 4-8, 1971 (Acta Endocrinol. (Copenhagen), Suppl. 155 (1971), 168). 
At present no simple technique is available that permits the completely satisfactory determination of transcortin activity. Numerous principles have been applied to its measurement in blood: equilibrium dialysis (2), gel filtration $(3,4)$, ultrafiltration (5), and paper electrophoresis (6) as well as immunologic (7), enzymatic (8), and adsorption procedures (9). Isotopic gel filtration belongs to the most widely used methods in transcortin analysis. The information thus obtained on the various parameters characterizing steroid-protein interactions is limited to the quantitation of the cortisol binding capacity of transcortin. In view of its convenience, gel filtration may be regarded as the preferable technique for comparative clinical studies provided that identical experimental conditions are rigorously maintained $(10,11)$. However, certain methodological disadvantages concerning reliability and practicability are associated with the original gel filtration procedures:

1) the possible in-vitro-interference with cortisol binding to transcortin by other steroids of possibly unknown structure and/or quantity; and

2) the necessity for the fluorometric or colorimetric measurement of protein-bound cortisol.

A modification was therefore developed based on the elimination of steroids from plasma by adsorption and subsequent saturation of the stripped binding sites of transcortin with a definite amount of labeled cortisol prior to gel filtration. In addition, data will be presented on the incomplete dissociation of the albumin-cortisol complex during column chromatography with Sephadex at $4{ }^{\circ} \mathrm{C}$. In spite of the unspecific residual cortisol binding to albumin, the reliability of the method described appeared to be only insignificantly influenced.

\section{Materials}

\section{Reagents}

Except for Sephadex G-50 medium (Deutsche Pharmacia, Frankfurt/M) and Norit-A charcoal (Serva, Heidelberg), all reagents were purchased from E. Merck, Darmstadt (reagentgrade). Organic solvents were redistilled prior to use.

\section{Steroids}

Crystalline cortisol was obtained from Schering AG (Berlin) and used without further purification. $\left[4-{ }^{14} \mathrm{C}\right]$ cortisol (specific activity: $159 \mu \mathrm{Ci} / \mathrm{mg}$; radiochemical purity: $96 \%$ ) was purchased from The Radiochemical Centre (Amersham, England) and purified once a month by thinlayer chromatography (solvent system: chloroform/ethanol, volumes, $80 \mathrm{ml}+20 \mathrm{ml}$ ). The steroids were stored in benzene/methanol (volumes, $90 \mathrm{ml}$ $+10 \mathrm{ml}$ ) solutions at $4{ }^{\circ} \mathrm{C}$.

\section{Proteins}

Crystalline human serum albumin was obtained from Behringwerke AG, Marburg/Lahn (RH 20; electrophoretic purity: $100 \%$ ). ${ }^{131}$ I-labelled Albumin (specific activity: $25 \mu \mathrm{Ci} / \mathrm{mg}$; radio chemical purity: $98 \%$ ) was purchased from Hoechst (Frankfurt) M). The proteins were stored at $4^{\circ} \mathrm{C}$ and used without further purification.

\section{Apparatus}

included jacketed chromatography colums K 9/30 (Dt. Pharmacia, Frankfurt/M); cooling device TK 64, ultrathermostat HT 13, automatic fraction collector UltroRac LKB 7000, photometer Uvicord II LKB 8300 A, LKB recorder $6520 \mathrm{H}$ (all purchased from Colora, Lorch/Württ.).

\section{Radioactivity}

was measured in a Tri-Carb liquid scintillation spectrometer 3380 (Packard, Frankfurt/M) using the scintillation fluid described by Bray (12). A mean counting efficiency of $71 \%$ wạs obtained.

\section{Method}

\section{Samples}

The cortisol binding capacity of transcortin was determined in heparinized plasma samples. Subjects were 13 healthy male adults, 15 healthy, nonpregnant female adults, 8 patients with total gonadal insufficiency, 12 pregnant patients at the end of the tenth lunar month, and 35 nonselected patients who had taken oral contraceptives over periods ranging from one month to five years. Samples were stored in a deep freezer at $-20^{\circ} \mathrm{C}$ up to six months. After thawing fibrin clots were removed by centrifugation.

\section{Elimination of endogenous steroids}

(stripping) was accomplished by a modification of the method described by Heyns et al. (9). $200 \mathrm{mg}$ of uncoated charcoal were added to $4 \mathrm{ml}$ of test plasma. The mixture was shaken mechanically in a water bath for $30 \mathrm{~min}$ at $46^{\circ} \mathrm{C}$. The adsorbent was then removed by centrifugation ( $10 \mathrm{~min}$ at 4,000 r. p. m.) and subsequent filtration over Schleicher \& Schüll paper No. 595. Both steps were carried out twice.

\section{Saturation of transcortin binding sites}

$1.0 \mathrm{ml}$ of a solution containing $0.200 \mu \mathrm{Ci}$ of $\left[4-{ }^{14} \mathrm{C}\right]$ cortisol and $2.000 \mu \mathrm{g}$ of cortisol in benzene/methanol (volumes, $90 \mathrm{ml}+10 \mathrm{ml}$ ) was evaporated to dryness under a stream of nitrogen. The radioactivity ( $\mathrm{pCi}$ ) of an aliquot of the saturation solution was always counted and used as a basis for the calculation of the cortisol binding capacity of transcortin. $2.0 \mathrm{ml}$ of stripped undiluted plasma were added to the remaining film of dry cortisol. The sample was then allowed to equilibrate at $37^{\circ} \mathrm{C}$ for $60 \mathrm{~min}$. in a water bath with gentle shaking. Prior to chromatography, the overloaded plasma was cooled at $4{ }^{\circ} \mathrm{C}$ for at least one hour.

\section{Isolation of transcortin-bound cortisol}

Sephadex G-50 medium was suspended in phosphate buffer $(0.15 \mathrm{~mol} / 1 ; \mathrm{pH} 7.4)$. After elimination of fines from the gel, a jacketed column $(9 \times 300 \mathrm{~mm})$ was packed at room temperature to a height of $27 \mathrm{~cm}$ (bed volume corresponding to $1.7 \mathrm{~g}$ of Sephadex). Prior to use, the column was equilibrated at $4^{\circ} \mathrm{C} .0 .3 \mathrm{ml}$ of test plasma saturated with cortisol was then placed on the column and allowed to drain into the gel. This was followed by two $0.5-\mathrm{ml}$ washes with buffer before elution was initiated at a flow rate of $1 \mathrm{ml}$ per min. The eluate was collected in 1-ml portions directly into the counting vials. Identification of the protein fraction was achieved by ultraviolet photometry at $280 \mathrm{~nm} .10 \mathrm{ml}$ of scintillation fluid were added to those por tions showing less than $100 \%$ transmittance, and radioactivity was subsequently determined. After emergence of the void volume (about $5 \mathrm{ml}$ ), which was discarded, the proteins and protein-bound radioactivity were always found between fractions 6 and 11. As a control procedure the next four 1-mlportions were also analyzed. In preliminary experiments, recovery of $\left[4-{ }^{14} \mathrm{C}\right]$ cortisol ranged between 98 and $100 \%$ (60 determinations), while elution of plasma equilibrated with ${ }^{131} \mathrm{I}$ labelled albumin resulted in a protein recovery of $97 \%$ (2 deter minations). After each completed run, the column was washed with $40 \mathrm{ml}$ of buffer and then reused for another assay. 


\section{Calculation of the cortisol binding capacity of transcortin}

By equilibrating the stripped plasma sample with cortisol in excess of its binding capacity, the binding sites of transcortin are saturated with the steroid. Since the specific activity of the solution used in the overloading step is known, the measure of

${ }^{14} \mathrm{C}$-carbon in the protein fraction is also a measure of the amount of protein-bound cortisol. This in turn is a measurc of cortisol binding capacity of transcortin provided that the albumin-cortisol complex dissociates completely during the gel filtration procedure. Therefore, the cortisol binding capacity of transcortin ( $\mu \mathrm{g}$ of transcortin-bound cortisol per 1 of plasma) can be calculated directly by the following equation:

$$
\mathrm{TC}-\mathrm{BC}=\text { transcortin-bound } \mathrm{pCi} \times 1 / \mathrm{SA} \times \mathrm{C} \text {, }
$$

where transcortin-bound $\mathrm{pCi}$ is the radioactivity contained in the protein eluate, 1/SA the reciprocal value of the specific activity of the saturation solution ( $\mu \mathrm{g}$ of cortisol per $\mathrm{pCi}$ ), and $C$ the factor necessary for conversion of $\mu \mathrm{g}$ of cortisol bound per sample volume $(0.3 \mathrm{ml})$ to $\mu \mathrm{g}$ bound per 1 of plasma.

\section{Results}

\section{Elimination of endogenous steroids}

Two stripping procedures were compared with regard to their efficiency and practicability.

(A) Gel filtration.at $46{ }^{\circ} \mathrm{C}$ (4) of plasma saturated with $\left[4-{ }^{14} \mathrm{C}\right.$ ] cortisol (overloading dose: $2 \mathrm{mg} / \mathrm{l}$ ) reduced the amount of labeled steroid eluted in the protein fraction to very low values (recovery of protein-bound radioactivity: $4.9 \pm 1.3 \% ; n=4)$.

(B) In order to evaluate the adsorption technique originally described by Heyns et al. (9) plasma saturated with labeled cortisol (overloading dose: $2 \mathrm{mg} / \mathrm{l}$ ) was incubated with increasing amounts of powdered charcoal at room temperature and at $46^{\circ} \mathrm{C}$, respectively.

Table 1 indicates that equilibration with $50 \mathrm{mg}$ of Norit A per $1 \mathrm{ml}$ of plasma for $30 \mathrm{~min}$ at $46^{\circ} \mathrm{C}$ results in almost complete adsorption of $\left[4-{ }^{14} \mathrm{C}\right]$ cortisol (recovery of radioactivity: $1.7 \%$ ). An incubation period of $30 \mathrm{~min}$ at $46^{\circ} \mathrm{C}$ was adequate to bring about the desired stripping effect (Norit-A concentration: $50 \mathrm{mg} / \mathrm{ml}$ ): ${ }^{14} \mathrm{C}$-carbon recovery was reduced to $3.2 \%$ after $5 \mathrm{~min}$, it was lowered to $2.2 \%$ after $15 \mathrm{~min}$ and reached a value of $1.7 \%$ after $30 \mathrm{~min}$. Extending the duration of incubation to $60 \mathrm{~min}$ did not improve efficiency (recovery of labeled cortisol: 1.6\%).

Tab. 1. Elimination of $\left[4-^{14} \mathrm{C}\right]$ cortisol from plasma by adsorption onto charcoal: Dependence on Norit-A concentration and incubation temperature.

\begin{tabular}{lll}
\hline $\begin{array}{l}\text { Norit-A concentration } \\
(\mathrm{g} / \mathrm{l} \text { plasma })\end{array}$ & \multicolumn{2}{l}{$\begin{array}{l}\text { Recovery of labeled cortisol } \\
(\%)\end{array}$} \\
$\begin{array}{l}\text { at } \\
\text { room temperature }\end{array}$ & $\begin{array}{l}\text { at } \\
4{ }^{\circ} \mathrm{C}\end{array}$ \\
\hline 25 & 7.6 & 4.2 \\
50 & 5.7 & 1.7 \\
100 & 5.3 & 1.6 \\
\hline
\end{tabular}

Duration of incubation in all experiments: $30 \mathrm{~min}$
Tab. 2. Indirect comparison of the efficiency of two stripping methods.

\begin{tabular}{|c|c|c|}
\hline \multirow[t]{2}{*}{ Plasma } & \multicolumn{2}{|c|}{ Cortisol binding capacity of transcortin $(\mu \mathrm{g} / \mathrm{l})$} \\
\hline & Adsorption & Gel filtration at $46^{\circ} \mathrm{C}$ \\
\hline $\begin{array}{l}\text { N } 1 \\
\text { N } 2 \\
\text { N } 3\end{array}$ & $\begin{array}{l}270 \\
249 \\
253\end{array}$ & $\begin{array}{l}261 \\
225 \\
273\end{array}$ \\
\hline $\begin{array}{l}\text { P } 1 \\
\text { P } 2 \\
\text { P } 3\end{array}$ & $\begin{array}{l}655 \\
670 \\
617\end{array}$ & $\begin{array}{l}687 \\
631 \\
579\end{array}$ \\
\hline
\end{tabular}

Cortisol load in all experiments: $2000 \mu \mathrm{g} / \mathrm{l} ; \mathrm{N} \mathrm{1-3}=$ plasma of healthy males; $P$ 1-3 = late pregnancy plasma.

Table 2 shows the results of an indirect comparison of the two stripping methods. In six duplicate determinations the cortisol binding capacity of transcortin was determined by isotopic gel filtration at $4{ }^{\circ} \mathrm{C}$ after removal of endogenous steroids from plasma by adsorption on charcoal or gel filtration at $46^{\circ} \mathrm{C}$, respectively (prior to the final chromatography, the depleted samples had been saturated with $2 \mathrm{mg}$ of labeled cortisol per 1 of plasma). No significant differences were observed indicating that full binding activity was retained regardless of the stripping procedure applied.

Due to its higher degree of practicability and relatively better efficiency the adsorption technique was used routinely for the elimination of steroids from plasma.

\section{Nonspecific cortisol binding to albumin}

The amount of cortisol necessary to saturate the stripped binding sites of transcortin was analyzed (Fig. 1). Both in normal and late pregnancy plasma we observed a linear elevation of the cortisol binding capacity values with increasing cortisol loads. Equilibration of human serum albumin (crystalline albumin dissolved in phosphate buffer $\mathrm{pH} 7.4 ; 40 \mathrm{~g} / \mathrm{l}$ ) with increasing amounts of labeled cortisol, followed by column chromatography at $4{ }^{\circ} \mathrm{C}$, also-resulted in a similar rise of radioactivity appearing in the protein eluate, although it was of considerably lesser magnitude (Fig. 1). These data demonstrate the incomplete

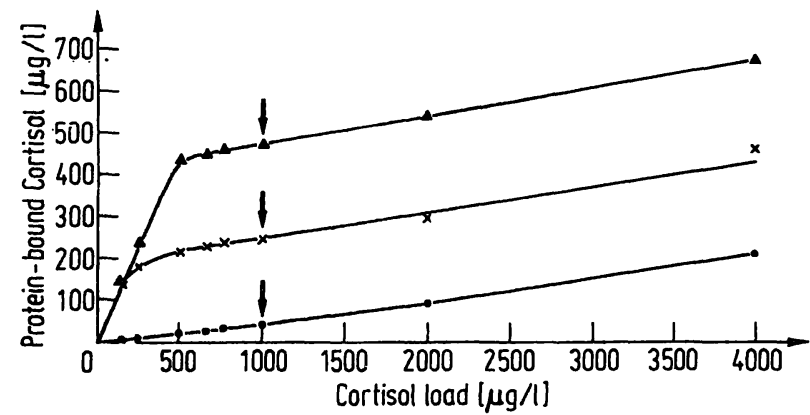

Fig. 1. Cortisol-binding capacity of plasma $(x-x$ normal; $\Delta$ late pregnancy) and purified albumin $(40 \mathrm{~g} / \mathrm{l}$, $\bullet-)$ : Dependence on cortisol load. $\downarrow=$ routine cortisol load. 
dissociation of the albumin-cortisol complex during gel filtration at $4^{\circ} \mathrm{C}$. However, if one subtracts the nonspecific binding to albumin from the values obtained with normal and late pregnancy plasma, it be- . comes obvious that the mean levels of presumably transcortin-bound cortisol do not change significantly despite increasing overloading doses (Fig. 2). In order to allow for sufficient saturation of the binding sites of transcortin, while at the same time minimizing the residual cortisol binding to albumin, the cortisol load was kept as low as $1 \mathrm{mg}$ per 1 of plasma in the routine procedure.

Gel filtration at $4{ }^{\circ} \mathrm{C}$ of cortisol-saturated buffer solutions containing varying amounts of purified albumin $(20,40$, and $80 \mathrm{~g} / \mathrm{l})$ showed that the extent of nonspecific binding to albumin under standard assay conditions is only insignificantly enlarged by an increase in albumin concentraction (Tab. 3). Likewise, the in-

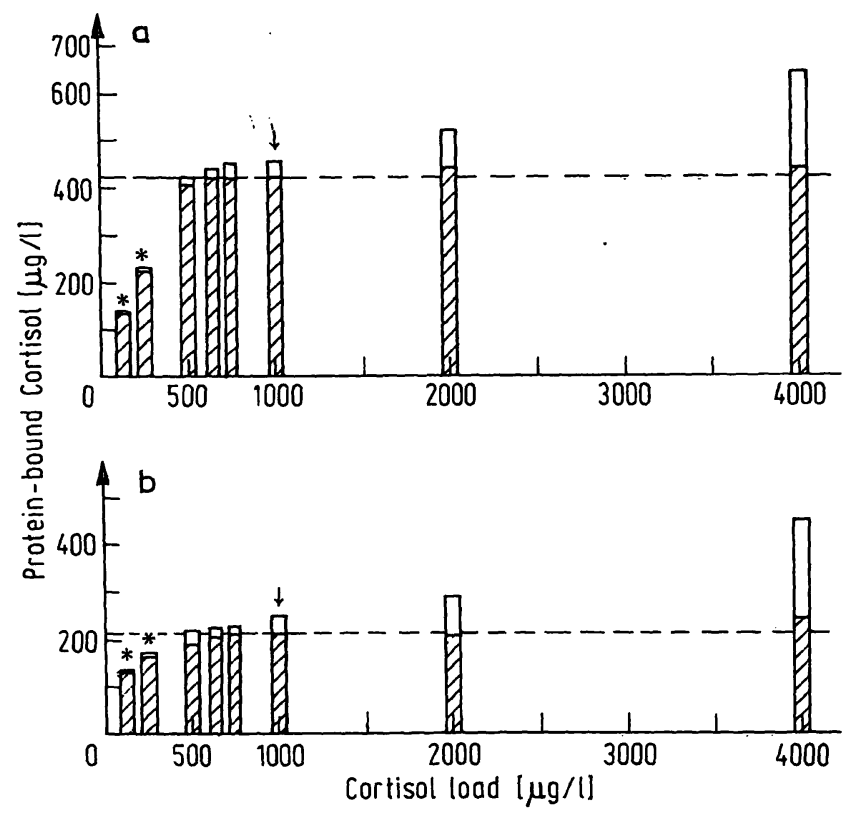

Fig. 2. Cortisol binding to transcortin and albumin (a) late pregnancy plasma; b) normal plasma): Dependence on cortisol load. $*=$ insufficient cortisol load; $\downarrow$ = routine cortisol load; hatched part of columns $=$ transcortinbound cortisol; nonhatched part of columns = albuminbound cortisol; $-\ldots-$ = mean value of transcortin-bound cortisol.

Tab. 3. Cortisol binding to purified albumin: Dependence on cortisol load and albumin concentration.

\begin{tabular}{lrrr}
\hline Cortisol load & \multicolumn{3}{l}{ Human serum albumin } \\
& $80 \mathrm{~g} / 1$ & $40 \mathrm{~g} / 1$ & $20 \mathrm{~g} / 1$ \\
Cortisol $\mu \mathrm{g} / 1$ & & & \\
\hline 4000 & 182 & 212 & 138 \\
2000 & 98 & 91 & 66 \\
1000 & 44 & 38 & 34 \\
500 & 22 & 20 & 13 \\
\hline
\end{tabular}

Tab. 4. Cortisol binding capacity of transcortin of human plasma: Influence of added albumin.

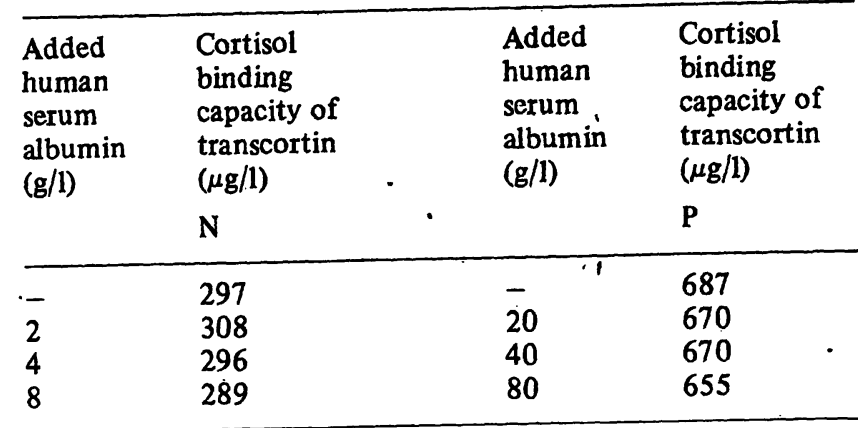

Cortisol load in all experiments: $2000 \mu \mathrm{g} / \mathrm{l}$;

$\mathrm{N}=$ plasma of a healthy male;

$\mathrm{P}=$ Late pregnancy plasma

vitro-addition of crystalline albumin to plasma samples caused no marked change of the cortisol-binding capacity as determined by the combined adsorption-gel filtration procedure (Tab. 4). In a further experiment, transcortin of normal and mid-pregnancy plasma was inactivated selectively and irreversibly by heating for $30 \mathrm{~min}$ at $60^{\circ} \mathrm{C}(13)$ after elimination of endogenous steroids. The samples were subsequently saturated and then submitted to column chromatography at $4^{\circ} \mathrm{C}$. Analysis of the protein-bound cortisol fraction indicated that the extent of residual cortisol binding to albumin is independent of transcortin levels: it amounted to $41 \mu \mathrm{g} / \mathrm{l}$ in a healthy male and to $39 \mu \mathrm{g} / \mathrm{l}$ in a pregnant female at mid-term (cortisol binding capacity of transcortin of the unheated controls: 193 and $390 \mu \mathrm{g} / \mathrm{l}$, respectively). In routine determinations of the cortisol binding capacity of transcortin for comparative clinical studies, the values obtained were not corrected for nonspecific binding to albumin.

\section{Application to human plasma}

Cortisol binding capacity of transcortin under physiological, pathological and contraceptive conditions as measured by the present modification is illustrated in Figure 3. The mean values were $261 \pm 23$ (S. D.) $\mu \mathrm{g} / \mathrm{l}$ in 13 healthy males, $255 \pm 31 \mu \mathrm{g} / \mathrm{l}$ in 15 healthy nonpregnant female adults, and $560 \pm 82 \mu \mathrm{g} / 1$ in 12 pregnant females prior to delivery. Normal results were obtained in 8 patients with total gonadal insufficiency $(241 \pm 27 \mu \mathrm{g} / \mathrm{l})$. However, administration of oral contraceptives over periods ranging from one month to five years induced a highly significant increase in the cortisol binding capacity (t-test for unpaired variates: $\mathrm{p}<0.001$ ): $428 \pm 53 \mu \mathrm{g} / \mathrm{l}$ in 20 patients receiving Ortho Novum 1/50 (Cilag-Chemie, Alsbach/Bergstraße; $50 \mu \mathrm{g}$ of mestranol $+1 \mathrm{mg}$ of norethindrone per day), and $542 \pm 64 \mu \mathrm{g} / 1$ in 15 patients taking Eugynon (Schering $\mathrm{AG}$, Berlin; $50 \mu \mathrm{g}$ of ethinylestradiol $+0.5 \mathrm{mg}$ of $D, L$ norgestrel). 


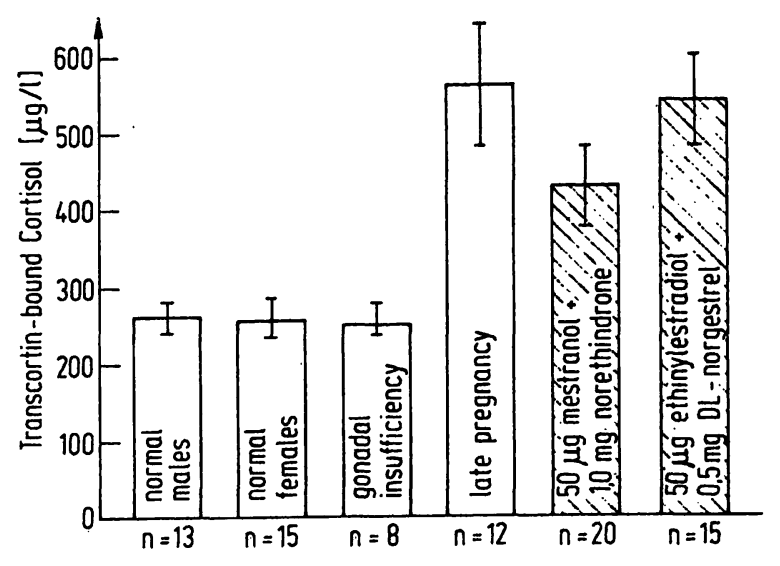

Fig. 3. Cortisol binding capacity of transcortin under physiological, pathological and contraceptive conditions (nonselected patients on oral contraceptives for periods ranging from 4 weeks to 5 years).

\section{Sensitivity and precision}

Figure 4 demonstrates the relative sensitivity of the method described. Various volumes of phosphate buffer $\mathrm{pH} 7.4(1,2,3$, and $4 \mathrm{ml})$ were added to assay tubes, and the final volume was made up to $6 \mathrm{ml}$ with plasma of a healthy male. Duplicate determinations of the cortisol binding capacity of transcortin were then carried out with $0.3 \mathrm{ml}$ aliquots of these plasma dilutions. The assay proved to be linear over a threefold range $(\mathrm{r}=0.9992 ; \mathrm{p}<0.001)$.

For assessment of reproducibility, sixtuplicate deter: minations were performed by a single technician on aliquots of identical material (normal and late pregnancy plasma, respectively) in a single day using the same batches of reagents (within-assay variability) as well as on six consecutive days using different batches of reagents (between-assay variability). In addition, we evaluated the between-technician variability by calculating the mean standard deviation of 89 nonselected duplicate determinations run by two different operators in the course of one year. Table 5 shows the high degree of precision of the combined adsorption-gel filtration technique.

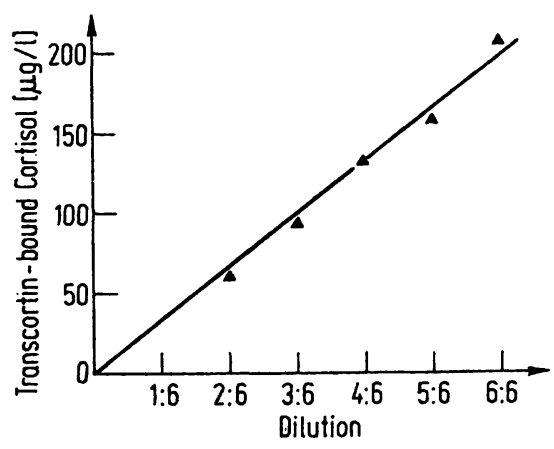

Fig. 4. Cortisol binding capacity of transcortin of various plasma dilutions.
Tab. 5. Precision of the combined adsorption-gel filtration assay a) Cortisol binding capacity of transcortin sixtuplicate determinations of the same sample by one technician.

\begin{tabular}{lcccc}
\hline Parameter & \multicolumn{2}{l}{$\begin{array}{l}\text { Within-assay } \\
\text { variability }\end{array}$} & \multicolumn{3}{c}{$\begin{array}{l}\text { Between-assay } \\
\text { variability }\end{array}$} \\
& $\mathrm{N}$ & $\mathrm{P}$ & $\mathrm{N}$ & $\mathrm{P}$ \\
\hline$\overline{\mathrm{x}}(\mu \mathrm{g} / \mathrm{l})$ & 237 & 456 & 238 & 450 \\
S. D. $(\mu \mathrm{g} / \mathrm{l})$ & 4 & 6 & 6 & 11 \\
CV $(\%)$ & 1.7 & 1.3 & 2.5 & 2.4 \\
\hline
\end{tabular}

$\mathrm{N}=$ plasma of a healthy malc; $\mathrm{P}=$ late pregnancy plasma;

b) Cortisol binding capacity of transcortin duplicate determinations of various samples by two technicians

\begin{tabular}{lll}
\hline $\begin{array}{l}\text { Cortisol binding capacity } \\
\text { of transcortin rangc } \\
(\mu \mathrm{g} / \mathrm{l})\end{array}$ & $\begin{array}{l}\text { S. D. of duplicate determinations } \\
(\mu \mathrm{g} / \mathrm{l}) \\
\text { Technician A }\end{array}$ & Technician B \\
\hline $200-300$ & $\pm 10(\mathrm{n}=37)$ & $\pm 4(\mathrm{n}=11)$ \\
$400-600$ & $\pm 12(\mathrm{n}=30)$ & $\pm 6(\mathrm{n}=10)$ \\
\hline
\end{tabular}

\section{Discussion}

Gel filtration is a generally accepted principle for the isolation of transcortin-bound cortisol. As a nonequilibrium procedure characterized by small, but continuous dissociation of the transcortin-cortisol complex, it yields submaximal values for the cortisol binding capacity of transcortin. However, the dialysis effect can be reduced to a negligible minimum by proper choice of temperature, $\mathrm{pH}$, amount of Sephadex, column dimensions, sample volume and elution rate. Provided that assay conditions are strictly standardized and that the interpretation of results is kept within its theoretical limits, this technique represents a reliable and convenient method especially suited for comparative clinical studies.

Two basic requirements for the validity of experimental data obtained by the gel filtration procedure are (A) that the cortisol binding capacity of transcortin remains per definition unchanged after saturation of all binding sites of transcortin is attained, and

(B) that the albumin-cortisol complex dissociates completely during Sephadex chromatography at $4{ }^{\circ} \mathrm{C}$ because of its low association constant.

However, in disagreement with previous reports by $D e$ Moor et al. (3) and Doe et al. (4), we noted that, despite gel filtration at low temperature, a portion of cortisol is bound to purified albumin depending on the quantity of cortisol used in the overloading step. The linear elevation of protein-bound cortisol observed in plasma samples with rising cortisol loads may be explained by this effect, since cortisol in excess of the limited cortisol binding capacity of transcortin is bound to albumin. The extent of nonspecific cortisol binding 
appeared to depend solely on the overloading dose. It remained practically unaffected by increases in plasma albumin, as shown by analysis of samples with human serum albumin concentrations approaching levels three times higher than the upper physiological limit. When employing a cortisol load of $1 \mathrm{mg}$ per 1 of plasma, as in the routine procedure, the amount of albumin-bound cortisol entering values of the cortisol binding capacity of transcortin proved to be fairly small and constant (approximately $40 \mu \mathrm{g} / \mathrm{l}$ ). It is suggested that this systematic error occurs with all techniques utilizing nonsteady-state gel filtration. For practical reasons we do not consider it essential in comparative clinical studies to correct the individual data for residual cortisol binding to albumin; however, if a higher degree of specificity and accuracy is desired, the exact magnitude of this systematic error can be determined following selective heat inactivation of transcortin (13).

Combining the Sephadex column procedure with an adsorption technique improves the reliability and practicability of the assay.

A major limitation of the original method regarding specificity and accuracy orginates from the competition of various endogenous steroids with cortisol for binding sites on transcortin. It has been shown that progesterone displaces cortisol from its specific binding protein during pregnancy, thus causing an underestimation of the true cortisol binding capacity of transcortin $(10,14)$. Similar effects possibly induced e. g. by synthetic progestins administered for contraceptive purposes cannot be ruled out at present. Another disadvantage associated with the original gel filtration technique stems from the utilization of fluorometric or colorimetric assays for the quantitation of protein-bound cortisol. Application of either method may result in an overestimation of the actual cortisol binding capacity of transcortin if nonspecific fluorescents or PorterSilber chromogens other than cortisol were present. Substituting a competitive protein-binding assay for these procedures should increase the degree of accuracy; however, it would still be rather time-consuming.

The use of charcoal-treated samples saturated with a definite amount of labeled cortisol prior to gel filtration not only eliminates the possible inhibition of specific cortisol binding by other steroids, but also permits the direct radioactive measurement of the cortisol binding capacity of transcortin. The introduction of the adsorption step provides for complete removal of endogenous steroids from plasma without damaging transcortin. Other stripping procedures seem to be less or not at all suitable: Extraction with organic solvents leads to an irreversible denaturation of transcortin, whereas dialysis against bovine albumine at $40^{\circ} \mathrm{C}$ fails to remove the endogenous steroids sufficiently (15). Gel filtration at $46{ }^{\circ} \mathrm{C}$ (16; own experiments) or at $\mathrm{pH} 5.0-5.5$ (17) brings about the desired stripping effect, yet it lacks the technical simplicity of the adsorption technique.

The combined adsorption-gel filtration method meets the reliability criteria defined by Borth (18). It proved to be specific, since the isolated protein fraction exhibited the same properties as transcortin (10): It bound approximately $260 \mu \mathrm{g}$ of cortisol per 1 of plasma. No difference was observed between healthy male and female adults. Total gonadal insufficiency did not

Tab. 6. Estimates of the cortisol binding capacity of transcortin from the literature

\begin{tabular}{|c|c|c|c|}
\hline \multirow[t]{2}{*}{ Reference } & \multirow[t]{2}{*}{ Method } & \multirow{2}{*}{$\begin{array}{l}\text { Cortisol binding capacity } \\
\text { of transcortin }(\mu \mathrm{g} / \mathrm{l}) \\
\mathrm{N}\end{array}$} & . \\
\hline & & & $\mathbf{P}$ \\
\hline Daughaday et al. (2) & equilibrium dialysis & $201 \pm 52$ & \\
\hline Westphal (19) & equilibrium dialysis & 260 & \\
\hline Mills (5) & ultrafiltration & 230 & \\
\hline Keane et al. (20) & ultrafiltration & $261 \pm 43$ & $547 \pm 156$ \\
\hline Osorio and Schats (6) & paper electrophoresis & $228 \pm 36$ & \\
\hline Leybold et al. (8) & enzymatic assay & $255 \pm 34$ & 423 \\
\hline Pegg and Keane (21) & competitive adsorption & $230 \pm 28$ & $467 \pm 71$ \\
\hline Trapp and West (22) & competitive adsorption & $186 \pm 19$ & $517 \pm 64$ \\
\hline Pirke and Stamm (23) & competitive adsorption & 221 & \\
\hline De Moor et al. (3) & gel filtration & $259 \pm 38$ & 562 \\
\hline Murphy and Pattee (24) & gel filtration & $309 \pm 45$ & \\
\hline Doe et al. (4) & gel filtration & $226 \pm 29$ & 500 \\
\hline Hoffmann and Westphal (16) & gel filtration & 269 & \\
\hline Burger et al. (25) & gel filtration & $240 \pm 80$ & \\
\hline Present study & gel filtration & $255 \pm 31$ & $560 \pm 82$ \\
\hline
\end{tabular}

$\mathrm{N}=$ normal plasma; $\mathrm{P}=$ pregnancy plasma 
result in reduced cortisol binding capacity of transcortin. A significant elevation was found only in pregnancy and after administration of estrogenic substances. The binding protein measured also displayed the expected temperature dependency: maximum values were recorded at $4{ }^{\circ} \mathrm{C}$, reversible inactivation was accomplished at $46^{\circ} \mathrm{C}$, while heating at $60^{\circ} \mathrm{C}$ caused irreversible denaturation. The procedure was also shown to be very accurate as our data are in close agreement with estimates published in the literature (Tab. 6). In addition, results had a high degree of precision (Table 5), and the relative sensitivity was quite satisfactory (Fig. 4). The described method combines good reliability with adequate practicability: it is simple to learn, reproducibility is excellent even in the hands of unskilled technicians, and 8 detcrminations can easily be performed by one person per day.

Considering the elimination of methodological disadvantages associated with the original gel filtration assay, the present modification seems to be a useful addition to the techniques already available for the quantitation of transcortin activity.

\section{References}

1. Musa, B. U., Seal, U. S. \& Doe, R. P. (1965), J. Clin. Endocrinol. Metab. 25, 1163-66.

2. Daughaday, W. H., Adler, R. E., Mariz, I. K. \& Rasinski, D. C. (1962), J. Clin. Endocrinol. Metab. 22, 704-10.

3. De Moor, P., Heirwegh, K., Heremans, J. F. \& DeclerckRaskin, M. (1962), J. Clin. Invest. 41, 816-27.

4. Doe, R. P., Fernandez, R. \& Seal, U. S. (1964), J. Clin. Endocrinol. Metab. 24, 1029-39.

5. Mills, I. H. (1962), Brit. Med. Bull. 18, 127-33.

6. Osorio, C. \& Schats, D. L. (1964), J. Clin. Endocrinol. Metab. 24, 1067-71.

7. Beier, F. R., Lahey, M. E. \& Heiner, D. C. (1963), Amer. J. Dis. Child. 106, 381-7.

8. Leybold, K., Rieper, J. \& Wcissbecker, L. (1967), Acta Endocrinol. (Copenhagen) 56, 99-106.

9. Heyns, W., van Baelen, H. \& de Moor, P. (1967), Clin. Chim. Acta 18, 361-70.

10. Sandberg, A. A., Rosenthal, H., Schneider, S. L. \& Slaunwhite, W. R. Jr. (1966), in Steroid Dynamics, p. 1-59, Academic Press, London-New York.

11. Westphal, U. (1969), in Methods in Enzymology, vol. XV, p. 761-96, Academic Press, London-New York.

12. Bray, G. B. (1960), Anal. Biochem. 1, 279-85.
13. Daughaday, W. H. \& Mariz, I. K. (1961), Metab. Clin. Exp. $10,936-50$.

14. Rosenthal, H. E., Slaunwhite, W. R. Jr. \& Sandberg, A. A. (1969), J. Clin. Indocrinol. Metab. 29, 352-67.

15. De Moor, P. \& Deckx, R. (1963), Acta Endocrinol. (Copenhaben) 44, 107-18.

16. Hoffmann, W. \& Westphal, U. (1969), Anal. Biochem. 32, 48-58.

17. Slaunwhite, W. R. Jr. \& Sandberg, A. A. (1970), Acta Endocrinol. (Copenhagen) Suppl. 147, 144.

18. Borth, R. (1952), Ciba Found. Coll. Endocrinol. 2, 45-56.

19. Westphal, U. (1967), Arch. Biochem. Biophys. 118, 556-67.

20. Keane, P. M., Pearson, J. \& Walker, W. H. C. (1969), J. Endocrinol. 43, 571-79.

21. Pegg. P. J. \& Kcane, P. M. (1969), Stcroids 14, 705-15.

22. Trapp, G. A. \& West, C. D. (1969), J. Lab. Clin. Med. 73, $861-71$.

23. Pirke, K. M. \& Stamm, D. (1972), Acta Endocrinol. (Copenhagen) $70,515-23$.

24. Murphy, B. E. P. \& Pattee, C. J. (1963), J. Clin. Endocrinol. Metab. 23, 459-64.

25. Burger, A., Laudat, P. \& Bricaire, H. (1970), Acta Endocrinol. (Copenhagen) 64, 602-9.

Prof. Dr. med. J. Hammerstein Ḱlinikum Steglitz Abt. f. Gynäkologie 1000 Berlin 47

Hindenburgdamm 30

Dr. Ulf Schwartz, Abt. für Gyn. Endokrinologie, Klinikum Steglitz, Freic Universität Berlin 1000 Berlin 45, Hindenburgdamm 30 
